\title{
ПОЛУЧЕНИЕ ВОДОРАСТВОРИМЫХ ПЕПТИДОВ ИЗ БИОМАССЫ ЛИЧИНОК MUSCA DOMESTICA И ИЗУЧЕНИЕ ИХ СВОЙСТВ
}

\section{L.S. Krylova, E.K. Remizov, K.Yu. Smirnova, E.I. Sorokataya, Ya.B. Drevko \\ OBTAINING HYDROSOLUBLE PEPTIDES FROM THE BIOMASS OF MUSCA DOMESTICA LARVAS AND STUDY OF THEIR PROPERTIES}

\begin{abstract}
Крылова Любовь Сергеевна - ст. лаб. каф. микробиологии, биотехнологии и химии Саратовского государственного аграрного университета им. Н. И. Вавилова, г. Саратов.

E-mail: krilovalyubov@yandex.ru

Ремизов Евгений Кириллович - асп. каф. микробиологии, биотехнологии и химии Саратовского государственного аграрного университета им. Н.И. Вавилова, г. Саратов.

E-mail: evg1994rem54@mail.ru
\end{abstract}

Смирнова Ксения Юрьевна - асп. каф. микробиологии, биотехнологии и химии Саратовского государственного аграрного университета им. Н. И. Вавилова, г. Саратов.

E-mail: smirnova.ku@mail.ru

Сорокатая Евгения Ивановна - канд. биол. наук, доц. каф. экологии и природопользования Красноярского государственного аграрного университета, г. Красноярск.

E-mail: prorektor_ur@kgau.ru

Древко Ярослав Борисович - канд. хим. наук, доц. каф. микробиологии, биотехнологии и химии Саратовского государственного аграрного университета им. Н.И. Вавилова, г. Саратов.

E-mail: drevko@list.ru

Цель исследования - выделение водорастворимых пептидов из биомассы личинок $M$. domestica и изучение их антимикробной активности. Задачи: подобрать условия высокоэффективной жидкостной хроматографии (ВЭЖX) для эфффективного разделения водорастворимых пептидов, выделить пептиды из биомассы личинок M. domestica, изучить антибактериальную активность. Экстракцию водорастворимых пептидов проводили 0,1 M фосфратно-солевым буфрером по разработан-
Krylova Lyubov Sergeevna - Senior Laboratory Assistant, Chair of Microbiology, Biotechnology and Chemistry, Saratov State Agrarian University named after N. I. Vavilov, Saratov.

E-mail: krilovalyubov@yandex.ru

Remizov Evgeny Kirillovich - Post-Graduate Student, Chair of Microbiology, Biotechnology and Chemistry, Saratov State Agrarian University named after N. I. Vavilov, Saratov.

E-mail: evg1994rem54@mail.ru

Smirnova Ksenia Yuryevna - Post-Graduate Student, Chair of Microbiology, Biotechnology and Chemistry, Saratov State Agrarian University named after N. I. Vavilov, Saratov.

E-mail: smirnova.ku@mail.ru

Sorokataya Evgenia Ivanovna - Cand. Biol. Sci., Assoc. Prof., Chair of Ecology and Environmental Management, Krasnoyarsk State Agrarian University, Krasnoyarsk.

E-mail: prorektor_ur@kgau.ru

Drevko Yaroslav Borisovich - Cand. Chem. Sci., Assoc. Prof., Chair of Microbiology, Biotechnology and Chemistry, Saratov State Agrarian University named after N. I. Vavilov, Saratov.

E-mail: drevko@list.ru

ной нами оригинальной методике, состоящей из последовательных стадий, таких как перерастворение, иентрифругирование и многократное высаливание белков сульфратом аммония. Далее нами были подобраны условия для разделения водорастворимых пептидов методом ВЭЖХ на колонке BioSep SEC S-2000 300×2120 мм при скорости потока 1 мл/мин и длине волны 280 нм, времени хроматографрирования 60 мин, объеме вводимой пробы 20 мкл u mемпературе $25^{\circ} \mathrm{C}$. Таким образом, нами 
было получено 6 белковых фрракций из биомассы личинок Musca domestica. Наибольший хроматограффический выход регистрировали у фрракции 5-й, он составил 38,84 \%, у 1-й и 2-й фрракции - 20,33 и 22,43 \% соответственно, у 3-й фрракции -11,87 \%, в 4-й и 6-й фрракциях в следовых количествах - 2,99 и 3,54 \% coomветственно. Изучена антимикробная активность выделенных белковых фрракций и доказано, что фрракция № 2 ингибирует рост следующих штаммов микроорганизмов: Bacillus cereusum. ATCC 11778, Candida albicans um. РКПГY-401/NCTC-885-653, Staphylococcus aureus um. ATCC 6538 (209-P); Salmonella typhimurium um. 1626. Полученные данные являются предпосылкой для разработки антимикробных препаратов на основе АМП.

Ключевье слова: водорастворимые пептиды, высокоэфффективная жидкостная хроматографрия, антимикробная активность.

The aim of the research was the isolation of hydrosoluble peptides from the biomass of $M$. domestica larvae and the study of their antimicrobial activity. To achieve this goal, the following tasks were set: to select high performance liquid chromatography (HPLC) conditions for effective separation of hydrosolublepeptides, to isolate peptides from the biomass of $M$. domestica larvae, to study antibacterial activity. Thehydrosoluble peptides with 0.1 $M$ phosphate-buffered saline were extracted according to original technique developed by the authors, consisting of successive stages, such as resolution, centrifugation, and multiple salting out of proteins with ammonium sulfate. Later the conditions for the separation of hydrosolublepeptides by HPLCon a BioSep SEC S-2000 300x2120 mm column at a flow rate of $1 \mathrm{ml} / \mathrm{min}$ and a wavelength of $280 \mathrm{~nm}$ were selected, chromatography time of 60 minutes, the volume of the injected sample was 20 $\mu \mathrm{l}$ and the temperature of $25^{\circ} \mathrm{C}$. Thus, 6 protein fractions from the biomass of Muscadomestica larvaewe were obtained. The highest chromatographic yield in fraction 5 was recorded, it amounted to $38.84 \%$, fractions 1 and $2-20.33$ and 22.43 $\%$, respectively, fraction $3-11.87 \%$, fractions 4,6 in trace amounts - 2.99 and $3.54 \%$, respectively. Antimicrobial activity of isolated protein fractions was studied and it was proved that fraction 2 inhibited the growth of the following microorganism strains: Bacillus cereus str. ATCC 11778, Candida albicansstr. 401/NCTC-885-653, Staphylococcus aureus str. ATCC 6538 (209-P); Salmonella typhimuriumstr. 1626.

Keywords: hydrosoluble peptides, high performance liquid chromatography, antimicrobial activity.

Введение. На настоящий момент известно более 2493 антимикробных пептидов [1, 2]. Антимикробные пептиды синтезируются различными организмами и являются ключевыми молекулами системы врожденного иммунитета, которая обеспечивает первую линию защиты от инфекций человека и животных [3]. Эти соединения составляют важную часть врожденного иммунитета макроорганизма и в перспективе могут рассматриваться в качестве дополнения и/или замены общепринятых антибиотиков в медицинской и ветеринарной практике в силу ряда преимуществ: широкий спектр действия, активность в отношении штаммов, резистентных к другим антибиотикам [4-6]. Несмотря на огромное количество публикаций на данную тему, на данный момент отсутствует достаточное количество информации по данной тематике для систематизации знаний. Научноисследовательская работа по выделению наиболее перспективных АМП может стать предпосылкой к разработке высокоэффективных антимикробных препаратов нового поколения и наряду с этим позволит решить проблемы нарушения микробиоценозов живых организмов, будет способствовать терапии заболеваний, вызываемых антибиотикорезистными штаммами, и может использоваться для профилактики заболеваний различной этиологии [6-8].

Цель исследования. Выделить водорастворимые пептиды из биомассы личинок комнатной мухи и изучить их антимикробную активность.

Задачи исследования: подобрать условия ВЭЖХ для эффективного разделения водорастворимых пептидов, выделить пептиды из биомассы личинок M. domestica, изучить антибактериальную активность.

Объекты и методы исследования. Для получения белковых фрракций использовали навеску биомассы личинок Musca domestica в количестве 300 г. Экстракцию водорастворимых пептидов проводили 0,1 М фоссратно-солевым буфером по разработанной нами оригинальной 
методике, состоящей из нескольких стадий, включающих в себя перерастворение, центрифугирование и многократное высаливание белков сульфратом аммония [9]. ВЭЖХ проводили на колонке BioSep S2000 300×2120 mm, при длине волны 280 нм, объем петли 1575 мкл, элюентом являлся $0,1 \mathrm{M}$ фосффатно-солевой буфер. Антимикробную активность полученных водорастворимых пептидов определяли в трех повторностях согласно методическим указаниям МУК 4.2.1890-04 «Определение чувствительности микроорганизмов к антибактериальным препаратам» [10]. В исследованиях использовали следующие культуры микроорганизмов: Staphylococcus aureus шт. ATCC 6538 (209-P), Salmonella typhimurium шт. 1626, которые были получены из государственной коллекции патогенных бактерий ФКУЗ РосНИПЧИ «Микроб» Роспотребнадзора; Bacillus cereus шт. ATCC 11778, предоставленный ФГУ «ВГНКИ»; Candida albicans шт. РКПГY-401/NCTC-885-65, полученный из лаборатории «Российская коллекция патогенных грибов» ГБОУ ВПО «Северо- западный государственный медицинский университет им. И.И. Мечникова» Минздрава России.

Результаты исследования и их обсуждение. Нами была разработана методика разделения водорастворимых пептидов на колонке BioSep SEC S-2000 с применением в качестве подвижной фразы фоссфатно-солевого буфера. Разделение проводилось на колонке BioSep SEC S-2000 300x2120 мм при скорости потока 1 мл/мин и длине волны 280 нм, времени хроматографирования 60 мин, объеме вводимой пробы 20 мкл и температуре $25^{\circ} \mathrm{C}$. Данная скорость потока являлась оптимальной для разделения пептидов, полученных из личинок Musca domestica. Уменьшение скорости потока подвижной фразы не приводило к лучшему разделению фракций, однако увеличивало время анализа, а увеличение скорости потока приводило к объединению фракций. Таким образом, методом высокоэфффективной жидкостной хроматографии из биомассы личинок было получено 6 белковых фракций (рис.).

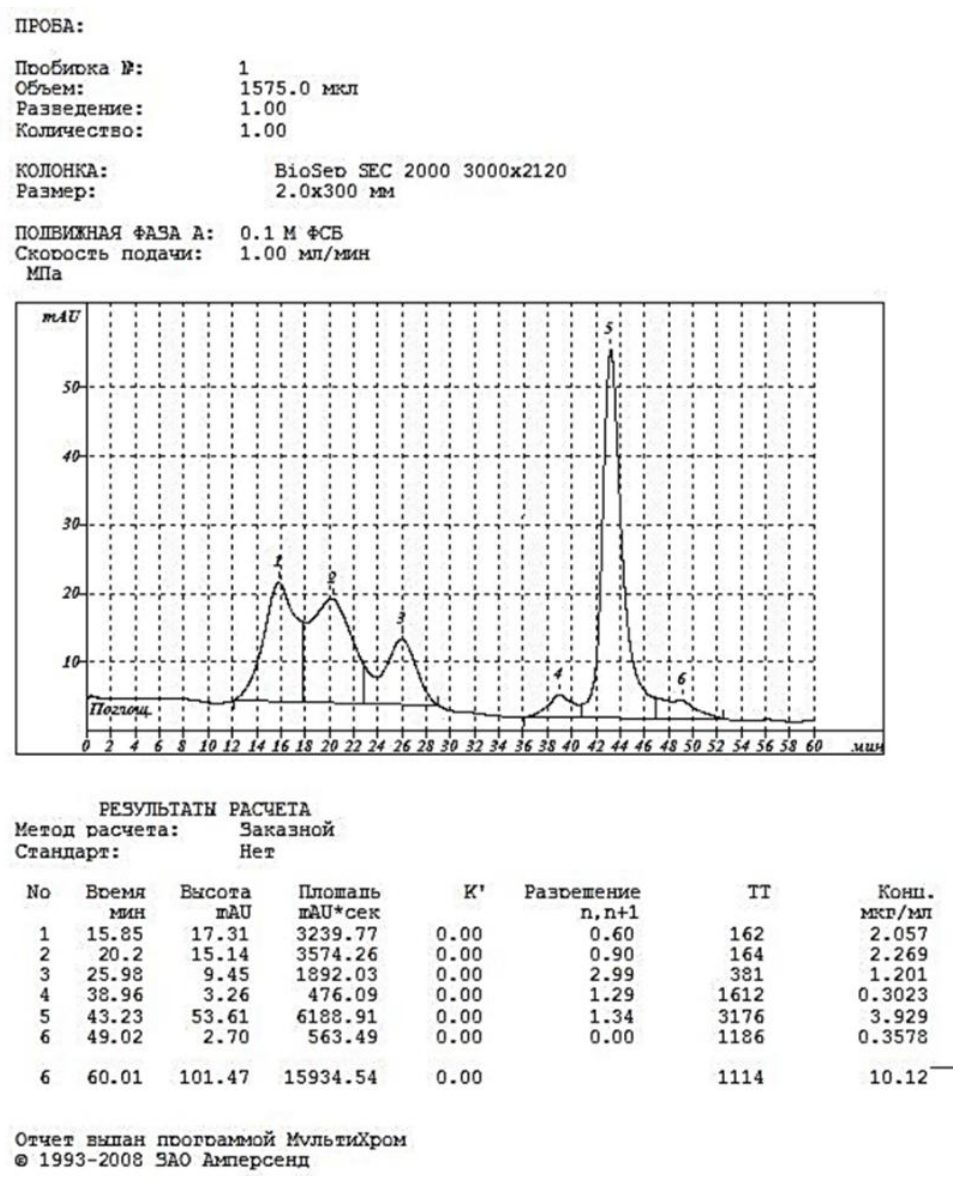

Хроматограмма белковых фрракций из биомассы личинок Musca domestica 
Хроматографический выход белковых фракций из биомассы личинок Musca domestica

\begin{tabular}{|c|c|c|}
\hline $\mathrm{tR}$ - время удерживания, мин & Площадь пика, $\mathrm{mAU}^{*}, \mathrm{c}$ & Хроматографический выход, $\%$ \\
\hline 15,85 & 3239,77 & $20,33 \%$ \\
\hline 20,20 & 3574,26 & $22,43 \%$ \\
\hline 25,98 & 1892,03 & $11,87 \%$ \\
\hline 38,96 & 476,09 & $2,99 \%$ \\
\hline 43,23 & 6188,91 & $38,84 \%$ \\
\hline 49,02 & 563,49 & $3,54 \%$ \\
\hline Сумма & 15934,55 & $100 \%$ \\
\hline
\end{tabular}

Таким образом, нами установлено, что наибольшей по содержанию водорастворимых пептидов в образце являлась фрракция № 5 со временем удерживания 43,23 мин и хроматографическим выходом 38,84 \%. Первая и вторая фракции со временем удерживания 15,85 и 20,20 мин соответственно были представлены в количествах 20,33 и 22,43 \%. Третья фрракция была представлена хроматографическим выхо- дом $11,87 \%$, а четвертая и шестая в следовых количествах 2,99 и 3,54 \% соответственно.

Исследования антимикробной активности проводили макрометодом в пробирках. По полученным нами данным из 6 фрракций водорастворимых пептидов антимикробной активностью по отношению ко всем использованным в данном исследовании штаммам обладала фракция № 2 (табл. 2).

Таблица 2

Антимикробная активность водорастворимых пептидов, полученных из биомассы личинок Musca domestica

\begin{tabular}{|c|c|c|c|c|}
\hline \multirow{2}{*}{$\begin{array}{c}\text { Номер } \\
\text { фракции } \\
\text { белка }\end{array}$} & $\begin{array}{c}\text { Staphylococcus } \\
\text { aureus шт. ATCC } \\
6538(209-P)\end{array}$ & $\begin{array}{c}\text { Salmonella } \\
\text { typhimurium шт. } \\
1626\end{array}$ & $\begin{array}{c}\text { Candida albicans шт. } \\
\text { РКПГҮ-401/NCTC- } \\
885-653\end{array}$ & $\begin{array}{c}\text { Bacillus cereus } \\
\text { шт. ATCC 11778 }\end{array}$ \\
\hline 1 & - & - & - & - \\
\hline 2 & + & + & + & + \\
\hline 3 & - & - & - & - \\
\hline 4 & - & - & - & - \\
\hline 5 & - & - & - & - \\
\hline 6 & - & - & - & - \\
\hline
\end{tabular}

Примечание: «-» - бульон мутный или есть осадок (антимикробная активность не выявлена); «+» - бульон прозрачный (выявлена антимикробная активность).

Выводы. По результатам проведенных исследований можно заключить, что разработанную нами методику следует использовать для разделения водорастворимых пептидов из биомассы личинок M. domestica. Полученные нами антимикробные пептиды обладают бактерицидным действием на изученные микроорганизмы. Данные по антимикробной активности пептидов можно использовать для дальнейшего изучения их антимикробной активности в отношении других инфеекционных агентов.

\section{Литература}

1. Wang G., Mishra B., Lau K., Lushnikova T.,Golla $R$., Wang X. Antimicrobial peptides in 2014 /I Pharmaceuticals. 2015. V. 8. P.123-150.

2. Józefiak A., Engberg R.M. Insect proteins as a potential source of antimicrobial peptides in livestock production. A review // Journal of Animal and Feed Sciences. 2017. V. 26. P. 87-99.

3. Lai Y., Gallo R.L. AMPed Up immunity: how antimicrobial peptides have multiple roles in 
immune defense // Trends Immunol. 2009. Vol. 30, № 3. P. 131-141.

4. Сьчева М.В. Биологические эфрфекты антимикробных веществ животного и бактериального происхождения: дис. ... д-ра биол. наук. Уфра, 2016. 274 с.

5. Diamond G., Beckloff N., Weinberg A., Kisich K.O. The roles of antimicrobial peptides in innate host Defense // Curr. Pharm. Des. 2009. Vol. 15, № 21. P. 2377-2392.

6. Крылова Л.С., Ремизов Е.К., Смирнова К.Ю. [и др.]. Индикация пептидов из биомассы личинок насекомых и изучение их антимикробной активности // Актуальные вопросы ветеринарной биологии. 2019. № 4 (44). С. 3-6.

7. Крылова Л.С., Амелькина А.А., Древко Я.Б. [и др.]. Изучение некоторых биологических свойств антимикробных пептидов, полученных из гемолимфы личинок Galleria mellonella // Актуальные проблемы ветеринарной медицины, пищевых и биотехнологий: мат-лы Междунар. науч.-практ. конф. Саратов, 2017. С. 263-267.

8. Крылова Л.С., Ларионова О.С., Древко Я.Б. Выделение антимикробных пептидов методом высокоэффективной жидкостной хроматографиии из личинок Galleria mellonella и изучение некоторых их свойств // Биотехнология: состояние и перспективы развития: мат-лы IX междунар. конгресса. М., 2017. С. 478-480.

9. Патент RU 2714128. Композиция антимикробных пептидов, полученных из личинок Musca domestica, и способ ее получения I Крылова Л.С., Древко Б.И., Фауст Е.А., Ремизов Е.К., Смирнова К.Ю., Древко Я.Б., Бородина М.А., Осина Т.С., Ларионова О.С. Опубл. 12.02.2020.

10. МУК 4.2.1890-04. Определение чувствительности микроорганизмов к антибактериальным препаратам: метод. указания. Введ. 2004-03-04. М.: Федеральный центр госсанэпиднадзора Минздрава России, 2004. $91 \mathrm{c}$.

\section{Literatura}

1. Wang G., Mishra B., Lau K., Lushnikova T.,Golla $R$., Wang X. Antimicrobial peptides in 2014 // Pharmaceuticals. 2015. V. 8. P.123-150.
2. Józefiak A., Engberg R.M. Insect proteins as a potential source of antimicrobial peptides in livestock production. A review // Journal of Animal and Feed Sciences. 2017. V. 26. P. 87-99.

3. Lai Y., Gallo R.L. AMPed Up immunity: how antimicrobial peptides have multiple roles in immune defense // Trends Immunol. 2009. Vol. 30, № 3. P. 131-141.

4. Sycheva M.V. Biologicheskie jeffekty antimikrobnyh veshhestv zhivotnogo i bakterial'nogo proishozhdenija: dis. ... d-ra biol. nauk. Ufa, 2016. $274 \mathrm{~s}$.

5. Diamond G., Beckloff N., Weinberg A., Kisich K.O. The roles of antimicrobial peptides in innate host Defense // Curr. Pharm. Des. 2009. Vol. 15, № 21. P. 2377-2392.

6. Krylova L.S., Remizov E.K., Smirnova K.Ju. [i dr.]. Indikacija peptidov iz biomassy lichinok nasekomyh i izuchenie in antimikrobnoj aktivnosti // Aktual'nye voprosy veterinarnoj biologii. 2019. № 4 (44). S. 3-6.

7. Krylova L.S., Amel'kina A.A., Drevko Ja.B. [i dr.]. Izuchenie nekotoryh biologicheskih svojstv antimikrobnyh peptidov, poluchennyh iz gemolimfy lichinok Galleria mellonella // Aktual'nye problemy veterinarnoj mediciny, pishhevyh i biotehnologij: mat-ly Mezhdunar. nauch.-prakt. konf. Saratov, 2017. S. 263-267.

8. Krylova L.S., Larionova O.S., Drevko Ja.B. Vydelenie antimikrobnyh peptidov metodom vysokojeffektivnoj zhidkostnoj hromatografii iz lichinok Galleria mellonella i izuchenie nekotoryh in svojstv // Biotehnologija: sostojanie i perspektivy razvitija: mat-ly IX mezhdunar. kongressa. M., 2017. S. 478-480.

9. Patent RU 2714128. Kompozicija antimikrobnyh peptidov, poluchennyh iz lichinok Musca domestica, i sposob ee poluchenija / Krylova L.S., Drevko B.I., Faust E.A., Remizov E.K., Smirnova K.Ju., Drevko Ja.B., Borodina M.A., Osina T.S., Larionova O.S. Opubl. 12.02.2020.

10. MUK 4.2.1890-04. Opredelenie chuvstvitel'nosti mikroorganizmov $k$ antibakterial'nym preparatam: metod. ukazanija. Vved. 2004-0304. M.: Federal'nyj centr gossanjepidnadzora Minzdrava Rossii, 2004. $91 \mathrm{~s}$. 